\title{
Host-Tree Monoterpenes and Biosynthesis of Aggregation Pheromones in the Bark Beetle Ips paraconfusus
}

\author{
John A. Byers ${ }^{1}$ and Göran Birgersson ${ }^{2}$ \\ ${ }^{1}$ US Arid-Land Agricultural Research Center, USDA-ARS, 21881 North Cardon Lane, Maricopa, AZ 85138, USA \\ ${ }^{2}$ Chemical Ecology, Protection Biology, Swedish University of Agricultural Sciences, 230-53 Alnarp, Sweden
}

Correspondence should be addressed to John A. Byers, john.byers@ars.usda.gov

Received 12 January 2012; Accepted 15 March 2012

Academic Editor: Qing-He Zhang

Copyright ( $(2012$ J. A. Byers and G. Birgersson. This is an open access article distributed under the Creative Commons Attribution License, which permits unrestricted use, distribution, and reproduction in any medium, provided the original work is properly cited.

\begin{abstract}
A paradigm developed in the 1970s that Ips bark beetles biosynthesize their aggregation pheromone components ipsenol and ipsdienol by hydroxylating myrcene, a host tree monoterpene. Similarly, host $\alpha$-pinene was hydroxylated to a third pheromone component cis-verbenol. In 1990, however, we reported that amounts of ipsenol and ipsdienol produced by male Ips paraconfusus (Coleoptera: Scolytinae) feeding in five host pine species were nearly the same, even though no detectable myrcene precursor was detected in one of these pines (Pinus sabiniana). Subsequent research showed ipsenol and ipsdienol are also biosynthesized from smaller precursors such as acetate and mevalonate, and this de novo pathway is the major one, while host tree myrcene conversion by the beetle is the minor one. We report concentrations of myrcene, $\alpha$-pinene and other major monoterpenes in five pine hosts (Pinus ponderosa, P. lambertiana, P. jeffreyi, P. sabiniana, and P. contorta) of I. paraconfusus. A scheme for biosynthesis of ipsdienol and ipsenol from myrcene and possible metabolites such as ipsenone is presented. Mass spectra and quantities of ipsenone are reported and its possible role in biosynthesis of aggregation pheromone. Coevolution of bark beetles and host trees is discussed in relation to pheromone biosynthesis, host plant selection/suitability, and plant resistance.
\end{abstract}

\section{Introduction}

The California five-spined engraver, Ips paraconfusus (Lanier) (Coleoptera: Scolytinae), is an important pest of young pine forests in California and Oregon. Struble and Hall [1] state that "all pine species within the range of this beetle are attacked", although the beetle occurs most frequently on ponderosa pine (Pinus ponderosa Laws) at elevations from 600 to $1,400 \mathrm{~m}$ in California. Due to the pest status of this insect, extensive studies have been conducted to elucidate the pheromone signal concerning the biosynthetic, behavioral, and ecological aspects [2-4].

The aggregation pheromone produced by males has been identified as a synergistic blend of three components, $(S)$ (-)-ipsenol, $(S)$ - $(+)$-ipsdienol, and (4S)-cis-verbenol [5-7]. Ipsenol and ipsdienol are produced only in males when exposed to vapors of the host plant monoterpene, myrcene [8], and the quantitative relationships between precursor vapor concentration and pheromone products have been reported [9]. Hendry et al. [10] used $\mathrm{D}_{2}$-labelled myrcene to demonstrate that it can be converted in the male to ipsenol and ipsdienol under vapor exposure conditions. Unexposed control males contained no pheromone components, nor did females, even when exposed to myrcene vapors [9]. Another host monoterpene, $(-)$ - $\alpha$-pinene, in the vapor phase is converted to cis-verbenol in both sexes [11], and the relationship between increasing $(-)-\alpha$-pinene vapor concentration and increasing cis-verbenol production in both sexes has been quantified [12]. Based on the above studies and others, a paradigm was established that I. paraconfusus, and probably most other Ips species, use myrcene and $\alpha$-pinene in their host tree as precursors to ipsenol and ipsdienol and to cisverbenol, respectively.

However, this paradigm began to be questioned when Byers and Birgersson [13] reported that males of I. paraconfusus that had fed in five different host pine species produced almost identical amounts of the pheromone components ipsenol and ipsdienol, regardless of the concentration of 
myrcene in the host species fed upon. In fact, gray pine, Pinus sabiniana, had so little myrcene that it could not be detected by gas chromatography and mass spectrometry (GC-MS). Thus, a beetle would need to eat at least eight times its weight in oleoresin in order to have any chance of obtaining the required amounts of myrcene [13]. This appears unrealistic since males were observed to ingest phloem alone. Therefore, coevolution of host myrcene and bark beetle pheromone production in regard to host selection and suitability appears unlikely. On the other hand, the conversion of host $\alpha$-pinene to cis-verbenol appears to be the major pathway, and so in this case coevolution could occur. Here, we present a more complete analysis of the host pine monoterpenes in phloem and oleoresin from pines in 1985 presented in part in Byers and Birgersson [13], as well as additional data from 1986, and the mass spectra of ipsenone. We will discuss in more detail our previous findings in relation to knowledge about the biosynthesis of aggregation pheromone components in relation to behavior, physiology, and coevolution of host tree monoterpenes and bark beetle ecology.

\section{Materials and Methods}

Ips paraconfusus were reared from ponderosa pine ( $P$. ponderosa) and introduced into five host species of pine: ponderosa, sugar (P. lambertiana), Jeffrey (P. jeffreyi), gray (P. sabiniana), and lodgepole ( $P$. contorta) as reported earlier [13]. The latter species, however, is not listed as a primary host probably because it generally occurs at elevations above the range of $I$. paraconfusus [1]. Males were dissected from their nuptial chambers after five days, and the posterior two thirds of the alimentary canal was extracted in groups of eight in $150 \mu \mathrm{L}$ diethyl ether with $10 \mathrm{ng}$ heptyl acetate per $\mu \mathrm{L}$ as an internal standard. Three samples of phloem (dry weight of each about $22 \pm 7 \mathrm{mg}, \pm \mathrm{SD}, n=15$ ) not affected by beetle galleries (not oxidized) from each of the infested pine species were each extracted in $250 \mu \mathrm{L}$ diethyl ether with internal standard. Pheromone components and ipsenone in the hindgut extracts were identified and quantified by gas chromatography (GC) on a Hewlett-Packard model 5880 and by GC-MS on a Finnigan model 4021. GC analysis used a fused silica column $(0.2 \mathrm{~mm}$ i.d. $\times 12.5 \mathrm{~m})$ coated with SE-54 CL (General Electric, 1\% vinyl-, 5\% phenyl-, $94 \%$ methylpolysiloxane) on a temperature program of $60^{\circ} \mathrm{C}$ for $3 \mathrm{~min}$, rising to $220^{\circ} \mathrm{C}$ at $5^{\circ} \mathrm{C} / \mathrm{min}$, and isothermal for $15 \mathrm{~min}$. Nitrogen, $20 \mathrm{~cm} / \mathrm{s}$, was used as carrier gas. GC-MS used a column of fused silica $(0.15 \mathrm{~mm}$ i.d. $\times 25 \mathrm{~m}$, df $=$ $0.3 \mu \mathrm{m}$ ) coated with Superox FA (Alltech, TPA-treated PEG, $\mathrm{df}=0.3 \mu \mathrm{m})$ on a temperature program of $50^{\circ} \mathrm{C}$ for $4 \mathrm{~min}$, rising to $200^{\circ} \mathrm{C}$ at $8^{\circ} \mathrm{C} / \mathrm{min}$ and isothermal for $10 \mathrm{~min}$ and helium carrier gas at $35 \mathrm{~cm} / \mathrm{s}$. Synthetic chemical standards of ipsenol, ipsdienol, and cis-verbenol were obtained from Borregaard (Norway). Ipsenone was prepared by oxidation of ipsenol in Jones reagent [14].

The phloem extracts described above were analyzed by GC on the fused silica column of SE-54 above. GC-MS used the $\mathrm{SE}-54$ column on a program of $50^{\circ} \mathrm{C}$ for $1 \mathrm{~min}$, rising to $220^{\circ} \mathrm{C}$ at $5^{\circ} \mathrm{C} / \mathrm{min}$ and isothermal for $10 \mathrm{~min}$. Carrier gas was as described above. Synthetic monoterpenes used for reference spectra were obtained from Sigma-Aldrich. There was some question as to the species and chemical identification for Jeffrey and/or gray pine. This was because Jeffrey pine phloem contained large quantities of $\alpha$-pinene and myrcene relative to some of the other pines while Jeffrey pine was expected to contain mostly n-heptane $[15,16]$. Also, gray pine had virtually none of the monoterpene hydrocarbons. Therefore, phloem samples were collected Oct. 17, 1986, from four trees of each of the five species. Also one tree each of sugar pine and ponderosa pine were sampled in four cardinal directions to determine the variation in monoterpene hydrocarbon content between samples. Oleoresin was collected from each of the species except sugar pine in which resin flow was insufficient for collection. Chemical analyses were as described above.

\section{Results}

Extracts of the hindguts of the male $I$. paraconfusus that had fed on the five host pines contained only a few major components, with ipsenol and ipsdienol dominating (Figure 1). Ipsenone, the ketone of ipsenol, was observed (Figure 1) in I. paraconfusus males fed in ponderosa pine, sugar pine, Jeffrey pine, gray pine, and lodgepole pine at $161 \pm 124(\mathrm{ng} / \mathrm{male} \pm \mathrm{SD}), 115 \pm 83,111 \pm 85,86 \pm 41$, and $87 \pm 36$, respectively.

The quantities of ipsenol and ipsdienol in fed males in each of the pine species were reported previously [13]. The quantities of these two pheromone components were similar and not significantly different; while it appeared that males from Jeffrey and lodgepole pines had more cis-verbenol than those from the other species where it could not be detected [13]. Here, we report that correlations between ipsenol and ipsdienol were consistently high within host species $\left(R^{2}\right.$ from 0.64 to 0.97$)$, and an overall $R^{2}=0.85(N=25)$ for all species. However, correlations between ipsenone and ipsenol $\left(R^{2}=0, N=25\right)$ or ipsdienol $\left(R^{2}=0.14, N=25\right)$ were low.

The monoterpene hydrocarbons, myrcene and $\alpha$-pinene, in the infested logs, were found in the largest amounts in phloem of Jeffrey pine, with significant amounts in lodgepole pine, lower amounts in ponderosa and sugar pine, and undetectable levels in gray pine. These phloem samples showed a large variation (within tree) in monoterpene hydrocarbons (Table 1). Phloem samples from several trees of each of the five species taken in October 17, 1986, showed an even larger variation (between tree) in monoterpene hydrocarbons (Table 2), but the relative amounts were consistent with those of the previous year (Table 1). These results are in agreement with field observations of the phloem during the dissection of the logs where Jeffrey pine was observed to contain "many $1 \mathrm{~mm}$ diam. resin pockets", lodgepole as "resinous," gray as "not resinous," and sugar and ponderosa as "slightly resinous." The relative amounts of the major monoterpenes in oleoresin of four of the pine species (sugar pine oleoresin could not be obtained) were found in percentages similar to those for the phloem 


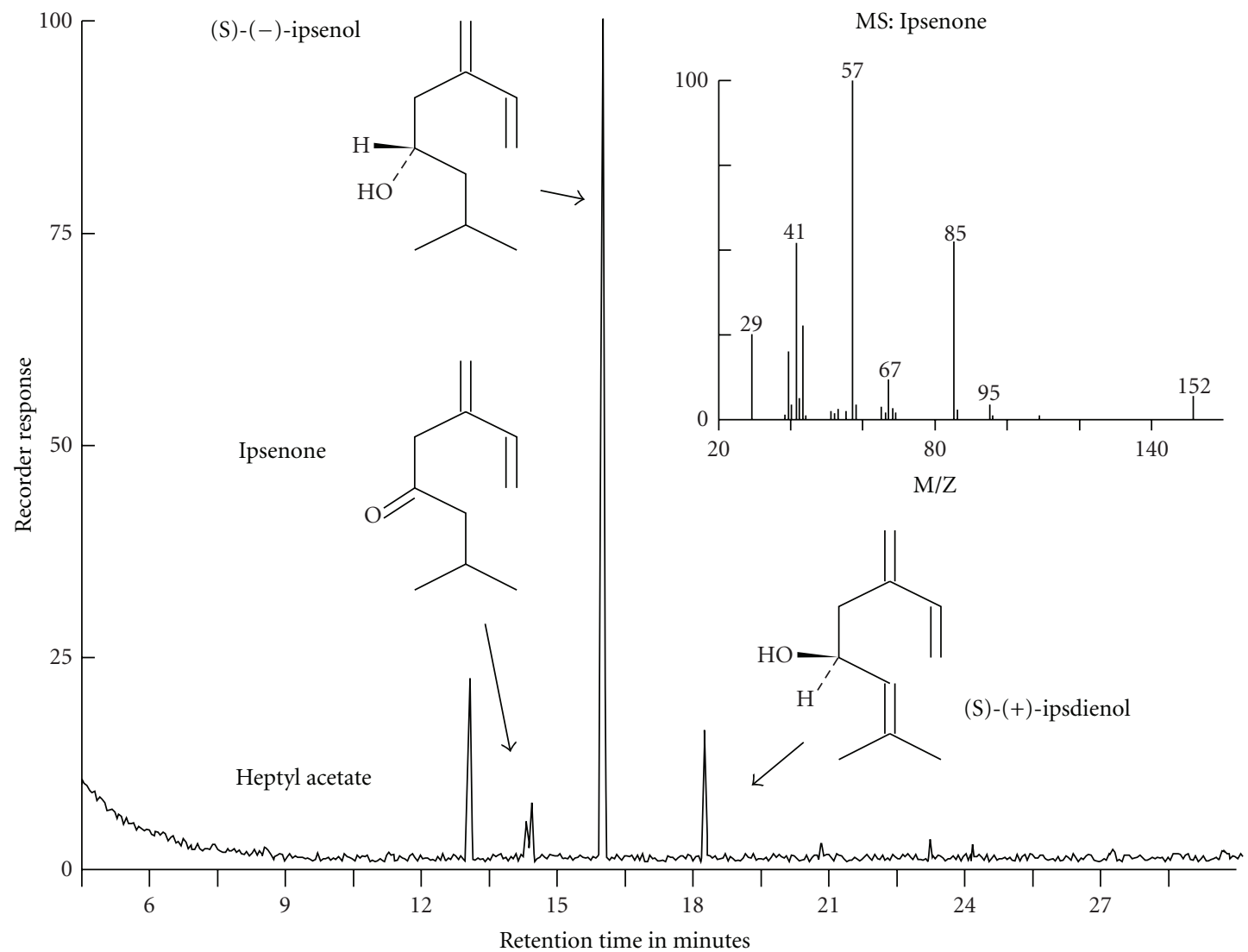

Figure 1: Gas chromatogram (Superox FA) of extract of hindguts of eight male Ips paraconfusus that had fed in Jeffrey pine. Heptyl acetate was used as an internal standard to quantify the pheromone components ipsenol and ipsdienol. Ipsenone, a related analog, eluted immediately before diacetone alcohol in a doublet peak. The mass spectrum of ipsenone is shown in the inset.

TABLE 1: Amounts of monoterpene hydrocarbons in phloem samples (15-25 mg dry weight) from five species of pine that were fed on by Ips paraconfusus (near Bass Lake, California, USA, September 3, 1985).

\begin{tabular}{|c|c|c|c|c|c|}
\hline \multicolumn{6}{|c|}{ Monoterpene hydrocarbons $(\mu \mathrm{g})$ per g phloem (dry weight) } \\
\hline Pine species & $\begin{array}{c}\alpha \text {-pinene } \\
\text { mean } \pm \mathrm{SD} \\
(\text { range })\end{array}$ & $\begin{array}{c}\beta \text {-pinene } \\
\text { mean } \pm \mathrm{SD} \\
(\text { range })\end{array}$ & $\begin{array}{c}\text { Myrcene } \\
\text { mean } \pm \mathrm{SD} \\
(\text { range })\end{array}$ & $\begin{array}{c}\text { 3-Carene } \\
\text { Mean } \pm \text { SD } \\
\text { (range) }\end{array}$ & $\begin{array}{c}\text { Limonene } \\
\text { mean } \pm \mathrm{SD} \\
(\text { range })\end{array}$ \\
\hline Ponderosa & $6.0 \pm 9.0$ & $1.1 \pm 0.5$ & $3.53 \pm 2.69$ & $21.7 \pm 32.7$ & $13.5 \pm 21.0$ \\
\hline$N=3^{1}$ & $(<1.3-16.4)$ & $(<1.3-1.7)$ & $(1.6-6.6)$ & $(<1.3-59.3)$ & $(<1.9-37.7)$ \\
\hline Sugar & $5.4 \pm 2.2$ & $<1.5$ & $2.5 \pm 0.1$ & $<1.9$ & $<1.9$ \\
\hline$N=3$ & $(3.8-7.9)$ & $(<1.5)$ & $(2.4-2.6)$ & $(<1.9)$ & $(<1.9)$ \\
\hline Jeffrey & $335.7 \pm 160$ & $116.9 \pm 52.2$ & $36.0 \pm 18.7$ & $246.3 \pm 107$ & $16.0 \pm 7.4$ \\
\hline$N=3$ & $(152-445)$ & $(56.6-147)$ & $(15.8-52.6)$ & $(129-338)$ & $(7.5-20.8)$ \\
\hline Gray & $<1.0$ & $<1.0$ & $<1.0$ & $<1.0$ & $<1.0$ \\
\hline$N=3$ & $(<1.0)$ & $(<1.0)$ & $(<1.0)$ & $(<1.0)$ & $(<1.0)$ \\
\hline Lodgepole & $50.5 \pm 22.5$ & $8.5 \pm 3.4$ & $26.4 \pm 11.0$ & $18.6 \pm 8.4$ & $695.3 \pm 297.8$ \\
\hline$N=3$ & $(35.0-76.3)$ & $(6.0-12.4)$ & $(18.6-39.0)$ & $(12.5-28.2)$ & (479-1035) \\
\hline
\end{tabular}

${ }^{1}$ Number of samples from each tree.

(Tables 1-3). However, the percentage of the oleoresin that consisted of monoterpene hydrocarbons was much higher in ponderosa $(83.5 \%)$ and lodgepole pine $(89.9 \%)$ than in Jeffrey pine (2.9\%); and gray pine oleoresin was only $0.08 \%$ monoterpene hydrocarbons (of those in Table 3 ).

\section{Discussion}

The similarity of chemical structure between the major host monoterpene, myrcene, and ipsenol and ipsdienol led Hughes [8] to propose that the tree's myrcene was a 
TABle 2: Amounts of monoterpene hydrocarbons in phloem samples (15-25 mg dry weight) from five species of pine (near Bass Lake, California, USA, 17 October 1986).

\begin{tabular}{|c|c|c|c|c|c|}
\hline \multicolumn{6}{|c|}{ Monoterpene hydrocarbons ( $\mu \mathrm{g})$ per g phloem (dry weight) } \\
\hline Pine species & $\begin{array}{c}\alpha \text {-pinene } \\
\text { mean } \pm \text { SD } \\
(\text { range })\end{array}$ & $\begin{array}{c}\beta \text {-pinene } \\
\text { mean } \pm \mathrm{SD} \\
(\text { range })\end{array}$ & $\begin{array}{c}\text { Myrcene } \\
\text { mean } \pm \text { SD } \\
(\text { range })\end{array}$ & $\begin{array}{c}\text { 3-Carene } \\
\text { mean } \pm \mathrm{SD} \\
(\text { range })\end{array}$ & $\begin{array}{c}\text { Limonene } \\
\text { mean } \pm \text { SD } \\
(\text { range })\end{array}$ \\
\hline Ponderosa & $1076 \pm 1904$ & $1179 \pm 1921$ & $428 \pm 338$ & $2747 \pm 2483$ & $2345 \pm 3997$ \\
\hline$N=4^{1}$ & $(<20-3930)$ & $(<50-4060)$ & $(<50-1015)$ & $(237-6750)$ & $(<50-8335)$ \\
\hline Sugar & $395 \pm 378$ & $180 \pm 224$ & $54 \pm 55$ & $121 \pm 145$ & $<15$ \\
\hline$N=4$ & $(97-1015)$ & $(425-577)$ & $(<15-131)$ & $(<15-307)$ & $(<15)$ \\
\hline Jeffrey & $1665 \pm 1612$ & $1216 \pm 1692$ & $272 \pm 291$ & $1924 \pm 1563$ & $4410 \pm 3673$ \\
\hline$N=4$ & $(601-3520)$ & $(124-3165)$ & $(75-606)$ & $(283-3395)$ & (1105-8365) \\
\hline Gray & $<20$ & $<20$ & $<20$ & $<20$ & $<20$ \\
\hline$N=4$ & $(<20)$ & $(<20)$ & $(<20)$ & $(<20)$ & $(<20)$ \\
\hline Lodgepole & $1400 \pm 1811$ & $3261 \pm 4595$ & $780 \pm 1034$ & $2413 \pm 3096$ & $14284 \pm 14566$ \\
\hline$N=4$ & $(<25-4060)$ & $(<25-10075)$ & $(<25-2300)$ & $(98-6965)$ & $(1095-35000)$ \\
\hline
\end{tabular}

${ }^{1}$ Number of trees.

TABLE 3: Amounts of monoterpene hydrocarbons in oleoresin samples from four species of pine (near Bass Lake, California, USA, 17 October 1986).

\begin{tabular}{lcccccr}
\hline & \multicolumn{5}{c}{ Monoterpene hydrocarbons $(\mu \mathrm{g})$ per $\mu \mathrm{L}$ oleoresin } \\
Pine species & $\alpha$-pinene & $\beta$-pinene & Myrcene & 3-Carene & Limonene & Monoterpene Percent of Oleoresin \\
\hline Ponderosa $^{1}$ & $43.5 \pm 6.4$ & $102.6 \pm 14.3$ & $120.5 \pm 19.6$ & $498.5 \pm 79.2$ & $70.0 \pm 12.7$ & 83.5 \\
Jeffrey & 1.32 & 1.00 & 3.37 & 16.35 & 6.93 & 2.9 \\
Gray & 0.68 & $<0.06$ & $<0.06$ & $<0.06$ & $<0.06$ & 0.08 \\
Lodgepole & 43.2 & 39.7 & 23.7 & 69.5 & 723.0 & 89.9 \\
\hline
\end{tabular}

${ }^{1}$ Four samples from cardinal directions of one tree, mean \pm SD.

precursor of these pheromone components in Ips. Evidence for this theory was based on exposure of Ips paraconfusus males to myrcene vapor and the subsequent production of compounds with GC retention times identical to ipsenol and ipsdienol [8]. Byers et al. [9] confirmed the identifications using GC-MS and behavioral assays and reported a malespecific increasing relationship between precursor vapor concentration and pheromone products. Hendry et al. [10] labeled myrcene with deuterium and established the direct conversion of myrcene vapor to the pheromone components. Hughes [8] suggested that ipsdienol was directly converted to ipsenol since topical application of ipsdienol on males resulted in ipsenol production. Fish et al. [17] supported this by using deuterium-labeled ipsdienol $(64 \% \mathrm{D})$ that was converted in males to labeled ipsenol $(25 \% \mathrm{D})$. Some deuterium at carbon 4 was lost suggesting that an alternate pathway to ipsdienone (ketone at carbon 4) and back again to ipsdienol was occurring before conversion to ipsenol. However, I. paraconfusus contained no detectable ipsdienone, although it may occur in small proportions accounting for the loss of deuterium on the recovered ipsdienol (59\% D). Fish et al. [17] showed that males could convert synthetic ipsdienone to ipsdienol, which was then converted to ipsenol.

In the present study, we did not find ipsdienone but instead ipsenone (also ketone at carbon 4) in feeding males (Figure 2) and this compound could explain the loss of deuterium in ipsenol $(25 \%$ D) by a reversible pathway.
Ipsenone can also explain the observed loss of deuterium in the recovered ipsdienol since it would be expected that a reversible pathway exists between ipsdienol and ipsenol. In fact, until ipsdienone is found in beetles naturally, it is more logical to assume that ipsenone rather than ipsdienone is involved in the deuterium loss observed earlier by Fish et al. [17]. Later work by Ivarsson et al. [18] found that when ${ }^{3} \mathrm{H}$-ipsdienone was injected into males, radiolabel was incorporated into both ipsenol and ipsdienol, found mainly in the metathorax, while incubation of male tissues with ${ }^{3} \mathrm{H}$ ipsdienone did not produce radiolabel in these components. In vitro incubation of tissues from I. paraconfusus with ${ }^{14} \mathrm{C}$-acetate gave radiolabeled ipsenone/ipsdienone, but these were not chromatographically separated.

Hughes $[8,20]$ hypothesized that aggregating pheromones in Dendroctonus and Ips are "waste products from the metabolism of terpenes that have secondarily been utilized as chemical messengers." According to this hypothesis one would expect no differences between the cis-verbenol and ipsenol/ipsdienol production in regard to vapor exposure and feeding conditions or between the sexes-but great differences are evident $[12,21]$. The cis-verbenol system appears to be a detoxification process in part, although males produce about twice as much cisverbenol, and the ratios with other metabolites are different than in females [12]. The ipsenol/ipsdienol system has clearly evolved beyond that of a simple detoxification process 

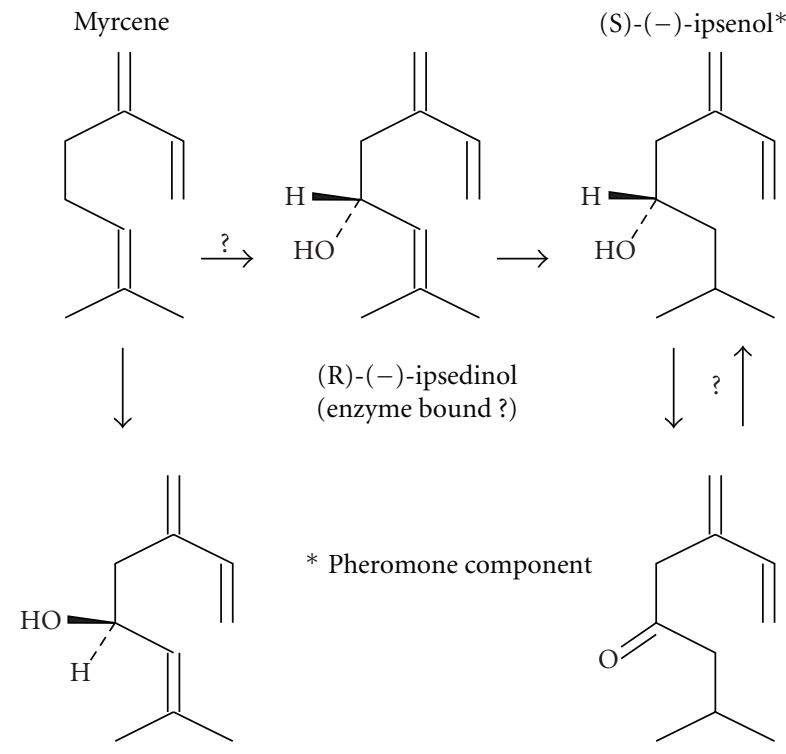

(R)-(-)-ipsedinol (enzyme bound?)

* Pheromone component

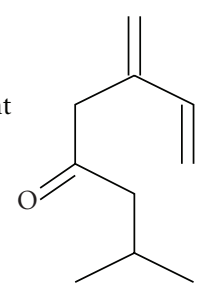

Ipsenone

(S)-(+)-ipsdienol*

Figure 2: Proposed scheme for the conversion of the host tree compound, myrcene, to the pheromone components $(S)-(-)$ ipsenol and $(S)-(+)$-ipsdienol in Ips paraconfusus based on radiolabelling experiments and enantiomers found in the male $[5,7-$ $12,17,19]$. Conversion arrows with question marks have not been proven. $(R)-(-)$-ipsdienol does not accumulate in the hindgut but may occur as an enzyme-bound intermediate. However, contrary to the scheme, the amounts of ipsenone, $(S)-(-)$-ipsenol and $(S)-(+)-$ ipsdienol in males were not correlated with myrcene titres in the host trees.

since this system (a) is sex-specific [9], (b) specifically influenced by juvenile hormone (JH) [22, 23], and (c) selectively inhibited by the antibiotic streptomycin [19]. The cis-verbenol system, on the other hand, is not affected by JH or streptomycin, and cis-verbenol is produced in both sexes, although females produced about half the amounts as males. Another difference between the ipsenol/ipsdienol and the cis-verbenol systems is that the male reduces his production of ipsenol and ipsdienol while feeding if he is joined by several females in his nuptial chamber [24]. The inhibition of pheromone production (and release) is physiological since males with females produced very little ipsenol and ipsdienol even when exposed to myrcene vapors, compared to males alone. In contrast, the production of cis-verbenol from $\alpha$-pinene vapors in males was not affected by females [24].

Earlier work provided intriguing suggestions that symbiotic microorganisms may convert myrcene to pheromone components. Byers and Wood [19] fed males in a diet of powdered cellulose and ground phloem (22\%) with and without streptomycin antibiotic. The males were removed from both diets and exposed to vapors of myrcene and $\alpha$ pinene whereupon only those in diets without streptomycinproduced ipsenol and ipsdienol (there was no affect of antibiotic on cis-verbenol production). However, Conn et al. [25] reported that axenically reared I. paraconfusus can produce their aggregation pheromones "completely

in the absence of the normal, extracellular complement of symbiotic microorganisms." Their data show that five axenic beetles produced half as much ipsenol as five feral (wild) beetles when feeding in logs and that axenic beetles without yeast as adults produced only about $10 \%$ the normal amounts. Hunt and Borden [26] repeated these tests and also found no significant statistical differences between axenic and control males, but again the axenic males produced only $36 \%$ as much ipsenol and ipsdienol. They also fed streptomycin to males and then introduced them into a ponderosa pine log. The ipsenol production in these males was reduced to only $2 \%$ indicating that both the feeding and aeration pathways are inhibited by the antibiotic $[19,26]$. No further work has implicated microorganisms, but in any case, it seems that the ipsenol/ipsdienol system is peculiarly sensitive to streptomycin.

According to the paradigm when our experiments were conducted (1985-1986), catches of I. paraconfusus on five species of host pines infested with conspecific males should be correlated with quantities of aggregation pheromone components ipsenol, ipsdienol, and cis-verbenol that were converted directly from myrcene and $\alpha$-pinene in the host trees. The attractions of I. paraconfusus to each of the five pine species of infested logs were similar except for an approximate doubling of catch on the Jeffrey pine log, as reported previously [13]. The sex ratios of catch (females per male) on four of the species were also similar (2.5 to 3.9) with more females than males, but the catch on Jeffrey pine was the most female biased (15.6) and this ratio was significantly different from the others [13]. The generally similar attraction to each of the pine species agrees with the similar amounts of the pheromone components, ipsenol and ipsdienol, found in the hindguts of the feeding males. However, there was no correlation between the widely varying amounts of myrcene in the host pines and the uniform amounts of ipsenol and ipsdienol in the males.

The increased catch on Jeffrey, and to a lesser extent on lodgepole, can be explained by the higher amounts of $\alpha$-pinene in the phloem that was converted to the third pheromone component, cis-verbenol [13]. Detection of cisverbenol in hindguts of feeding males is difficult [12], and Silverstein et al. [27] found that cis-verbenol occurred in quantities of only $2.5 \%$ the amount of ipsdienol in male frass. We found cis-verbenol to be $1 \%$ or $0.05 \%$ the amount of ipsdienol in hindguts of males feeding in Jeffrey and lodgepole pines, respectively. cis-Verbenol was presumably present in sufficient quantities in the males feeding in the other pines (although we could not quantify the amounts) as to be synergistically active with ipsenol and ipsdienol, since the latter two components have low activity without cisverbenol in the field [28].

The content of ipsenol and ipsdienol in groups of eight males (within or between species) was rather consistent [13] with a total $(n=25)$ coefficient of variation $(\mathrm{CV})$ of $26 \%$ for both ipsenol and ipsdienol. In comparison, the variations of the precursors $\alpha$-pinene and myrcene in phloem were much larger (Tables $1-3$ ), and the total CV for $\alpha$-pinene was $185 \%$ and for myrcene $126 \%$. Even within a tree the variation in $\alpha$-pinene and myrcene in phloem could be large (ranges 
in Table 1), which was probably the result of the rather small sample units (15-25 mg dry weight). Resin pockets are probably not evenly distributed in phloem so smaller samples would tend to vary more in the numbers of pockets. However, the sample unit was equivalent to about $80 \%$ of a nuptial chamber and thus indicates that beetles could ingest large differences between individuals in monoterpene hydrocarbons (calculation based on $[12,29]$ ). The amounts of myrcene and $\alpha$-pinene reported earlier [13] in the pine species as well as the other three major monoterpenes (Table 1) were considerably lower in phloem sampled in 1985 than they were in 1986 (Table 2). We are not sure why this was apparently the case unless the log's phloem had lost monoterpenes during the week-long behavioral tests in the field (1985) compared to immediate extraction of phloem cut from trees in 1986. Byers [12] showed that monoterpene vapors in male nuptial chambers in logs remain constant for about a week before declining rapidly in concentration.

Could males obtain enough myrcene in host phloem or oleoresin to account for the quantities of ipsenol and ipsdienol found in the hindguts? The male does not eat the entire contents of the nuptial chamber (fecal pellets appear to be a minor component of the frass), and it is doubtful that he selectively eats the "toxic" oleoresin [30-33]. The headspace concentration of myrcene in a nuptial chamber of ponderosa pine $\left(2.8 \times 10^{-8} \mathrm{~g} / \mathrm{mL}\right)$ [12] is expected to account for only $1.6 \%$ at most of the ipsenol in feeding males (by linear interpolation between lowest value and 0, Figure 1 in Byers et al. [9], note: equations should be $\mathrm{Y}=2.72+$ $1.05 \ln \mathrm{X}$ and $\mathrm{Y}=0.62+0.26 \ln \mathrm{X})$. Also, a feeding beetle must produce and release several times over the amounts found in hindguts at the end of the feeding period. The gut turnover rate (pheromone content of gut release per time) can be estimated from the airborne collection of components and gut contents. Studies with $D$. brevicomis $[34,35]$ can be used to calculate that females release exo-brevicomin at 16 gut contents per day at the peak of mass attack. $P$. chalcographus males release chalcogran at 18 gut contents per day [36, 37], and I. typographus males release 2-methyl-3buten-2-ol at about 240 gut turnovers/day and cis-verbenol at 48 turnovers/day $[38,39]$.

Assuming conservatively that gut turnover rates above are just 10 per day, then based on the quantities of myrcene in ponderosa pine phloem (fresh weight is $3.87 \times$ dry weight) [29] or oleoresin (Tables 1-3), a male would need to eat a minimum of from 99 to 413 nuptial chambers in the 1985 experiment (Table 1), or from 0.6 to 13 chambers in the 1986 samples (Table $2,111 \mu \mathrm{L}$ at $0.895 \mathrm{~g} / \mathrm{mL}$ ) to account for pheromone amounts [12]. However, only $0.14 \mu \mathrm{L}$ oleoresin is needed (1986 samples) to produce the estimated amounts of ipsenol and ipsdienol released over two days. Thus, I. paraconfusus would need to eat some oleoresin to account for pheromone production based on the myrcene precursor theory, as suggested earlier [12]. However, assuming amounts of myrcene in gray pine oleoresin of at most $0.06 \mu \mathrm{g} / \mu \mathrm{L}$ (our quantification limit), then at least $280 \mu \mathrm{L}$ of oleoresin from gray pine would be required (again assuming 100\% conversion). Thus, a beetle would need to eat more than 28 times its weight in oleoresin to have any possibility of producing the observed amounts of ipsenol and ipsdienol from eating gray pine. Even higher amounts of oleoresin would be required to replace pheromone released. Therefore, another biosynthetic pathway (de novo) is indicated since beetle's guts contain mostly phloem, and oleoresin is toxic to bark beetles (I. paraconfusus and D. brevicomis) [12, 3033]. Because small quantities of cis-verbenol are produced and required for attraction, it is probable that sufficient $\alpha$ pinene precursor is available from the host.

It is apparent that all five species of pine are about equally suitable as hosts, at least in terms of adult survival, nuptial chamber construction, pheromone production, and attraction [13]. Sugar pine is a soft pine (subgenus Haploxylon) while the others are hard pines (Diploxylon). However, sugar pine had monoterpene hydrocarbon characteristics more similar to ponderosa pine than these two species had with Jeffrey and gray pines. The Jeffrey pine with a low titer of $\alpha$ pinene and myrcene in the oleoresin is consistent with earlier reports [16] but the large amounts of oleoresin in its phloem were unexpected.

I. paraconfusus feeding in P. monticola and P. monophylla also appear to produce at least some of their pheromone components since I. montanus and I. confusus were significantly attracted [40]. I. paraconfusus can also produce attractant (pheromone) when boring in nonhosts Douglas fir in the laboratory [41] and white fir in the field [42]. In the latter species, however, it was shown that the amounts of ipsenol and ipsdienol were only one or two percent of the amounts produced in beetles feeding in ponderosa pine [42]. Differences in attractiveness of I. pini boring in two host species have also been observed [43], but it is not known which semiochemicals were responsible.

Elkinton et al. [42] proposed that evolution of host selection behavior by Ips bark beetles could have been influenced by the amounts of $\alpha$-pinene and myrcene in the tree needed for pheromone biosynthesis. Since $\alpha$-pinene in the tree appears to be converted to cis-verbenol, beetles may select trees high in this monoterpene. A related hypothesis is that tree genotypes lower in pheromone precursor monoterpenes may have evolved through natural selection [2]. This is doubtful since in the case of the ipsenol/ipsdienol system there does not appear to be any limitation in pheromone production when feeding in the wide variation of myrcenecontaining trees [13]. Thus coevolution of host selection and insect resistance does not seem to be occurring, except possibly with respect to $\alpha$-pinene. There does seem to be coevolution of detoxification genes for monoterpenes and tree genotypes, which has a major impact on host selection by Ips [44].

Assuming the detoxification theory was the first evolutionary stage of pheromone biosynthesis as proposed [8], then why was myrcene selected as the pheromone precursor instead of another monoterpene like limonene or 3-carene? Our results for ponderosa pine in 1985 show that myrcene and $\alpha$-pinene were found in four of the five pine species while sugar pine did not have detectable amounts of $\beta$ pinene, 3-carene, and limonene (Table 1). Myrcene had the least variation among the five monoterpenes in ponderosa pine in 1986 (Table 2). These data are limited, but Smith 
[45] sampled 74 areas across California and western USA and Canada and found that most areas had lower variation for myrcene and $\alpha$-pinene, while variation in 3 -carene, limonene, and $\beta$-pinene was higher (his Figure 7). In another study of 64 ponderosa pines, he reported that myrcene in oleoresin varied from 4.6 to $27.5 \%$ and $\alpha$-pinene from 1.5 to $13.3 \%$, while variation of limonene, $\beta$-pinene, and 3 -carene varied from 0 to 31,57 , and $82 \%$, respectively [46].

After the initial use of myrcene vapor as a precursor to ipsenol/ipsdienol in an Ips species, later speciation events appear to have evolved a de novo biosynthesis that now predominates in Ips species (at least in I. pini, I. paraconfusus, I. typographus, and I. duplicatus). Seybold et al. [47] state the benefits of "redundancy" would result by adding de novo biosynthesis and thus provide "assurance" of producing pheromone. Byers [2] argued that a de novo system would be advantageous to an individual since he could control the quantity of pheromone for optimal benefit and not be dependent on the host tree for precursor. The de novo system would be especially beneficial when a species radiates to use other host pines or when a particular host tree had unusually low amounts of precursor such as to limit pheromone production and fitness. In I. paraconfusus, a de novo system seems especially beneficial when colonizing host pines of species with little or no myrcene such as in gray pine as reported here and earlier [13]. The de novo systems of I. pini and I. paraconfusus could have become different with evolutionary time as the two species are moderately separated phylogenetically [48]. This is indicated by findings of Tillman et al. $[49,50]$, who showed that JH III from the corpora allata and by injection induced pheromone production in I. pini, but not as much in I. paraconfusus, compared to amounts in both species after feeding in host logs.

The aggregation pheromone components are essential to reproductive success, and thus, it may be too "risky" to rely on either levels of precursor in the tree or on generally available microorganisms - but rather generate the components de novo from acetate or mevalonate using the beetle's enzymatic systems [51]. As early as 1969, studies had shown that $I$. paraconfusus produced ipsenol and ipsdienol after application of JH analogues without feeding in hosts or exposure to myrcene $[22,23]$. This indicated that the corpora allata released $\mathrm{JH}$ due to feeding, which then stimulated de novo biosynthesis of the two aggregation pheromone components from energy reserves. Lanne et al. [52] showed that I. typographus can convert radiolabelled mevalonate to one of its two aggregation pheromone components, 2methyl-3-buten-2-ol, indicating that de novo pheromone biosynthetic pathways exist in Ips. Following this, Ivarsson et al. [53] injected an inhibitor of mevalonate biosynthesis into I. duplicatus and then allowed the beetles to feed in host Norway spruce. The accumulation of aggregation pheromone components $E$-mrycenol and ipsdienol were reduced 40 to $70 \%$, indicating these components are synthesized de novo when feeding via mevalonate. Although ipsdienol and $E$ mrycenol were found "to be produced de novo and not from myrcene" [51], exposure to myrcene did cause more of these two components to accumulate than controls, but only about
10 to $20 \%$ as much as application of $\mathrm{JH}$ analog or feeding in host alone.

Seybold et al. [54] provided further evidence that $I$. paraconfusus produces ${ }^{14} \mathrm{C}$-labeled ipsenol and ipsdienol (and traces of amitinol) de novo from injected ${ }^{14} \mathrm{C}$-labelled acetate prior to feeding in host logs. Similarly, in 1995, the same group showed that I. pini synthesized ${ }^{14} \mathrm{C}$-labeled ipsdienol (and large amounts of amitinol) from labeled acetate [54]. Interestingly, amitinol has not been reported as a major constituent of I. pini or I. paraconfusus aggregation pheromones, although its presence was noted in $I$. paraconfusus frass extracts [6]. JH III induced expression of regulatory enzymes (probably 3-hydroxy-3-methylglutarylCoA reductase $=$ HMG $-\mathrm{R}$ ) in I. paraconfusus metathoraxes to begin de novo isoprenoid pathways resulting in ipsenol and ipsdienol $[18,55]$. Hall et al. [56] localized the pheromone biosynthesis in I. pini to the anterior midgut (region just after the proventriculus). The HMG-R expression was in the anterior midgut, and when these and other tissues were incubated in vitro with radiolabeled acetate, then only the anterior midgut produced radiolabeled ipsdienol. The involvement of microbial symbionts was discounted since anterior midgut tissues when cut open and washed still incorporated radioactivity in ipsdienol. However, internal cell symbionts are still possible, if unlikely. Byers [21] found most ipsenol and ipsdienol in the rectum of I. paraconfusus; however, he dissected and extracted only the alimentary canal that is posterior to the anterior midgut. It is likely that although these components are produced in the anterior midgut epithelia, they migrate with the alimentary flow and accumulate in the rectum. Nardi et al. [57] provided electron micrographic evidence that the digestive secretory cells are interspersed with the pheromone-secreting cells in the anterior midgut. The pheromone-secreting cells are distinguished by many highly ordered arrays of smooth endoplasmic reticula. There was no evidence of internal symbiotic bacteria in this region [57].

Seybold and Tittiger [4] point out that JH III stimulated HGM-R enzyme activity in male I. pini, but not in male I. paraconfusus. Feeding in both species, however, induces HMG-R and pheromone production. It was found earlier that decapitated I. paraconfusus treated with JH were inhibited from producing pheromone, possibly due to a brain hormone from corpora cardiaca [23] that is not important in I. pini [4]. Mature (emerged) and callow (preemerged) adults of both sexes of I. paraconfusus do not contain detectable aggregation pheromone components, but after exposure to myrcene and $\alpha$-pinene vapors only the mature males produced ipsenol and ipsdienol, indicating certain "detoxification" enzyme systems become functional after maturity in males [21]. It is not known if HMG-R can be induced by JH in Ips, but in D. jeffreyi there is a weak activity compared to mature adults [4]. HMG-R is involved in the early (upstream) steps of isoprenoid biosynthesis that then diverges at isopentenyl diphosphate and geranyl diphosphate in scolytids [4]. Somehow, it seems that these diphosphate precursors are converted to myrcene, which is then hydroxylated by novel enzymes of each Ips species [4]. The question remains whether myrcene vapors play any role 
in pheromone biosynthesis or are merely artifacts of the manipulated near-saturation concentrations, since these can be about 70 times higher than in nuptial chambers [12]. Dietary myrcene could play a role, but in the case of $I$. paraconfusus feeding in gray pine with undetectable myrcene, the amounts of ipsenol and ipsdienol were similar to that produced when males fed in other host pines [13]. Seybold et al. [54] showed that the enantiomeric composition of ipsenol and ipsdienol is racemic when exposed to myrcene vapor, but specific enantiomers result when feeding. This shows that the de novo system is by far the major pathway.

Sandstrom et al. [58] isolated an NADPH-cytochrome $\mathrm{P} 450$ reductase that converted myrcene to the appropriate natural enantiomer $(4 R)-(-)$-ipsdienol in male I. pini. They concluded that this was a myrcene hydroxylase functioning near the end (downstream) of the pheromone biosynthetic pathway. A second report found that $I$. confusus in pinyon pine also had a cytochrome P450 enzyme that hydroxylated myrcene in males to about $85 \%(-)$-ipsdienol, similar to that in $I$. pini [59]. However, since $I$. confusus has a natural ipsdienol of $>90 \%(4 S)$ - $(+)$-ipsdienol, they state there are still additional enantio-specific enzymes that regulate the end product that have yet to be identified [59]. Since various species of Ips have different ratios of enantiomers of ipsenol and ipsdienol, then there are likely species-specific enzymes in the different species [59].

Further work is needed to determine the importance of the host tree monoterpene pathways that appear quantitatively minor (and more primitive?) compared to the major de novo pathways (derived?). It would also be interesting to determine when the biosynthetic pathways evolved in the various Ips species by using molecular clocks [60] and phylogenetic relationships of the biosynthetic genes (as done for other genes in Ips [61]).

\section{Acknowledgments}

The authors would like to thank D.L. Wood, University of California, Berkeley, and W. D. Bedard, P. E. Tilden, and M. I. Haverty, USFS, Berkeley and Oakhurst, Calif, for providing facilities and support for research in the field during 19851986. Support during this time was also provided by grants from the Swedish Agricultural and Forestry Research Council (SJFR) to Lund University, the Swedish University of Agricultural Sciences, and Göteborg University.

\section{References}

[1] G. R. Struble and R. C. Hall, "The California five-spined engraver. Its biology and control," USDA Circular, no. 964, pp. $1-21,1955$.

[2] J. A. Byers, "Chemical ecology of bark beetles," Experientia, vol. 45 , no. 3, pp. 271-283, 1989.

[3] J. A. Byers, "Host tree chemistry affecting colonization in bark beetles," in Chemical Ecology of Insects 2, R. T. Cardé and W. J. Bell, Eds., pp. 154-213, Chapman and Hall, New York, NY, USA, 1995.

[4] S. J. Seybold and C. Tittiger, "Biochemistry and molecular biology of de novo isoprenoid pheromone production in the
Scolytidae," Annual Review of Entomology, vol. 48, pp. 425453, 2003.

[5] R. M. Silverstein, J. O. Rodin, and D. L. Wood, "Sex attractants in frass produced by male Ips confusus in ponderosa pine," Science, vol. 154, no. 3748, pp. 509-510, 1966.

[6] R. M. Silverstein, J. O. Rodin, D. L. Wood, and L. E. Browne, "Identification of two new terpene alcohols from frass produced by Ips confusus in ponderosa pine," Tetrahedron, vol. 22, no. 6, pp. 1929-1936, 1966.

[7] D. L. Wood, L. E. Browne, W. D. Bedard, P. E. Tilden, R. M. Silverstein, and J. O. Rodin, "Response of Ips confusus to synthetic sex pheromones in nature," Science, vol. 159, no. 3821, pp. 1373-1374, 1968.

[8] P. R. Hughes, "Myrcene: a precursor of pheromones in Ips beetles," Journal of Insect Physiology, vol. 20, no. 7, pp. 12711275, 1974.

[9] J. A. Byers, D. L. Wood, L. E. Browne, R. H. Fish, B. Piatek, and L. B. Hendry, "Relationship between a host plant compound, myrcene and pheromone production in the bark beetle, Ips paraconfusus," Journal of Insect Physiology, vol. 25, no. 6, pp. 477-482, 1979.

[10] L. B. Hendry, B. Piatek, L. E. Browne et al., "In vivo conversion of a labelled host plant chemical to pheromones of the bark beetle Ips paraconfusus," Nature, vol. 284, no. 5755, p. 485, 1980.

[11] J. A. A. Renwick, P. R. Hughes, and I. S. Krull, "Selective production of cis- and trans- verbenol from (-) and (+) $\alpha$ pinene by a bark beetle," Science, vol. 191, no. 4223, pp. 199201, 1976.

[12] J. A. Byers, "Pheromone biosynthesis in the bark beetle, Ips paraconfusus, during feeding or exposure to vapours of host plant precursors," Insect Biochemistry, vol. 11, no. 5, pp. 563$569,1981$.

[13] J. A. Byers and G. Birgersson, "Pheromone production in a bark beetle independent of myrcene precursor in host pine species," Naturwissenschaften, vol. 77, no. 8, pp. 385-387, 1990.

[14] L. F. Fieser and M. Fieser, Reagents for Organic Synthesis, John Wiley and Sons, New York, NY, USA, 1967.

[15] N. T. Mirov, "Composition of gum turpentines of pines," USDA For Service Technical Bulletin 1239, 1961.

[16] R. H. Smith, "Variations in the monoterpene composition of the wood resin of Jeffrey, Washoe, Coulter and lodgepole pines," Forest Science, vol. 13, pp. 246-252, 1967.

[17] R. H. Fish, L. E. Browne, D. L. Wood, and L. B. Hendry, "Pheromone biosynthetic pathways: conversions of deuterium labelled ipsdienol with sexual and enantioselectivity in Ips paraconfusus lanier," Tetrahedron Letters, vol. 20, no. 17, pp. 1465-1468, 1979.

[18] P. Ivarsson, C. Tittiger, C. Blomquist et al., "Pheromone precursor synthesis is localized in the metathorax of Ips paraconfusus lanier (Coleoptera: Scolytidae)," Naturwissenschaften, vol. 85, no. 10, pp. 507-511, 1998.

[19] J. A. Byers and D. L. Wood, "Antibiotic-induced inhibition of pheromone synthesis in a bark beetle," Science, vol. 213, no. 4509, pp. 763-764, 1981.

[20] P. R. Hughes, "Dendroctonus: production of pheromones and related compounds in response to host monoterpenes," Journal of Applied Entomology, vol. 73, no. 3, pp. 294-312, 1973.

[21] J. A. Byers, "Influence of sex, maturity and host substances on pheromones in the guts of the bark beetles, Ips paraconfusus and Dendroctonus brevicomis," Journal of Insect Physiology, vol. 29, no. 1, pp. 5-13, 1983. 
[22] J. H. Borden, K. K. Nair, and C. E. Slater, "Synthetic juvenile hormone: induction of sex pheromone production in Ips confusus," Science, vol. 166, no. 3913, pp. 1626-1627, 1969.

[23] P. R. Hughes and J. A. A. Renwick, "Neural and hormonal control of pheromone biosynthesis in the bark beetle, Ips paraconfusus," Physiological Entomology, vol. 2, no. 2, pp. 117123, 1977.

[24] J. A. Byers, "Effect of mating on terminating aggregation during host colonization in the bark beetle, Ips paraconfusus," Journal of Chemical Ecology, vol. 7, no. 6, pp. 1135-1147, 1981.

[25] J. E. Conn, J. H. Borden, D. W. A. Hunt et al., "Pheromone production by axenically reared Dendroctonus ponderosae and Ips paraconfusus (Coleoptera: Scolytidae)," Journal of Chemical Ecology, vol. 10, no. 2, pp. 281-290, 1984.

[26] D. W. A. Hunt and J. H. Borden, "Terpene alcohol pheromone production by Dendroctonus ponderosae and Ips paraconfusus (Coleoptera: Scolytidae) in the absence of readily culturable microorganisms," Journal of Chemical Ecology, vol. 15, no. 5, pp. 1433-1463, 1989.

[27] R. M. Silverstein, J. O. Rodin, and D. L. Wood, "Methodology for isolation and identification of insect pheromones with reference to studies on California five-spined Ips," Journal of Economic Entomology, vol. 60, no. 4, pp. 944-949, 1967.

[28] D. L. Wood, R. W. Stark, R. M. Silverstein, and J. O. Rodin, "Unique synergistic effects produced by the principal sex attractant compounds of Ips confusus (LeConte) (Coleoptera: Scolytidae)," Nature, vol. 215, no. 5097, p. 206, 1967.

[29] F. W. Cobb Jr., D. L. Wood, R. W. Stark, and P. R. Miller, "Effect of injury upon physical properties of oleoresin, moisture content, and phloem thickness," Hilgardia, vol. 39, pp. 127134,1968

[30] R. H. Smith, "The fumigant toxicity of three pine resins to Dendroctonus brevicomis and D. jeffrei," Journal of Economic Entomology, vol. 54, no. 2, pp. 365-369, 1961.

[31] R. H. Smith, "Effect of monoterpene vapors on the western pine beetle," Journal of Economic Entomology, vol. 58, no. 3, pp. 509-510, 1965.

[32] R. H. Smith, "A physiological difference among beetles of Dendroctonus ponderosae (=D. monticolae) and D. ponderosae ( = D. jeffreyi)," Annals of the Entomological Society of America, vol. 58, no. 4, pp. 440-442, 1965.

[33] R. H. Smith, "Resin quality as a factor in the resistance of pines to bark beetles," in Breeding Pest-Resistant Trees, pp. 189-196, Pergamon Press, New York, NY, USA, 1966.

[34] L. E. Browne, D. L. Wood, W. D. Bedard, R. M. Silverstein, and J. R. West, "Quantitative estimates of the western pine beetle attractive pheromone components, exo-brevicomin, frontalin, and myrcene in nature," Journal of Chemical Ecology, vol. 5, no. 3, pp. 397-414, 1979.

[35] J. A. Byers, D. L. Wood, J. Craig, and L. B. Hendry, "Attractive and inhibitory pheromones produced in the bark beetle, Dendroctonus brevicomis, during host colonization: regulation of inter- and intraspecific competition," Journal of Chemical Ecology, vol. 10, no. 6, pp. 861-877, 1984.

[36] J. A. Byers, G. Birgersson, J. Löfqvist, M. Appelgren, and G. Bergström, "Isolation of pheromone synergists of bark beetle, Pityogenes chalcographus, from complex insect-plant odors by fractionation and subtractive-combination bioassay," Journal of Chemical Ecology, vol. 16, no. 3, pp. 861-876, 1990.

[37] G. Birgersson, J. A. Byers, G. Bergström, and J. Löfqvist, "Production of pheromone components, chalcogran and methyl (E,Z)-2,4-decadienoate, in the spruce engraver Pityogenes chalcographus," Journal of Insect Physiology, vol. 36, no. 6, pp. 391-395, 1990.
[38] G. Birgersson, F. Schlyter, J. Löfqvist, and G. Bergström, "Quantitative variation of pheromone components in the spruce bark beetle Ips typographus from different attack phases," Journal of Chemical Ecology, vol. 10, no. 7, pp. 10291055, 1984.

[39] G. Birgersson and G. Bergström, "Volatiles released from individual spruce bark beetle entrance holes quantitative variations during the first week of attack," Journal of Chemical Ecology, vol. 15, no. 10, pp. 2465-2483, 1989.

[40] G. N. Lanier and D. L. Wood, "Specificity of response to pheromones in the genus Ips (Coleoptera: Scolytidae)," Journal of Chemical Ecology, vol. 1, no. 1, pp. 9-23, 1975.

[41] D. L. Wood and R. W. Bushing, "The olfactory response of Ips confusus (LeConte) (Coleoptera: Scolytidae) to the secondary attraction in the laboratory," Canadian Entomologist, vol. 95, pp. 1066-1078, 1963.

[42] J. S. Elkinton, D. L. Wood, and L. B. Hendry, "Pheromone production by the bark beetle, Ips paraconfusus, in the nonhost, white fir," Journal of Chemical Ecology, vol. 6, no. 6, pp. 979-987, 1980.

[43] J. L. Piston and G. N. Lanier, "Pheromones of Ips pini (Coleoptera: Scolytidae). Response to inter populational hybrids and relative attractiveness of males boring in two host species," Canadian Entomologist, vol. 106, pp. 247-251, 1974.

[44] V. Thoss and J. A. Byers, "Monoterpene chemodiversity of ponderosa pine in relation to herbivory and bark beetle colonization," Chemoecology, vol. 16, no. 1, pp. 51-58, 2006.

[45] R. H. Smith, "Local and regional variation in the monoterpenes of ponderosa pine wood oleoresin," USDA Forest Service Research Paper, PSW-56, 1969.

[46] R. H. Smith, "Variation in the monoterpenes of Pinus ponderosa laws," Science, vol. 143, no. 3612, pp. 1337-1338, 1964.

[47] S. J. Seybold, J. Bohlmann, and K. F. Raffa, "Biosynthesis of coniferophagous bark beetle pheromones and conifer isoprenoids: evolutionary perspective and synthesis," Canadian Entomologist, vol. 132, no. 6, pp. 697-753, 2000.

[48] A. I. Cognato, "Phylogenetic analysis reveals new genus of Ipini bark beetle (Scolytidae)," Annals of the Entomological Society of America, vol. 93, no. 3, pp. 362-366, 2000.

[49] J. A. Tillman, G. L. Holbrook, P. L. Dallara et al., "Endocrine regulation of de novo aggregation pheromone biosynthesis in the pine engraver, Ips pini (Say) (Coleoptera: Scolytidae)," Insect Biochemistry and Molecular Biology, vol. 28, no. 9, pp. 705-715, 1998.

[50] J. A. Tillman, F. Lu, L. M. Goddard et al., "Juvenile hormone regulates de novo isoprenoid aggregation pheromone biosynthesis in pine bark beetles, Ips spp., through transcriptional control of HMG-CoA reductase," Journal of Chemical Ecology, vol. 30, no. 12, pp. 2459-2494, 2004.

[51] P. Ivarsson and G. Birgersson, "Regulation and biosynthesis of pheromone components in the double spined bark beetle Ips duplicatus (Coleoptera: Scolytidae)," Journal of Insect Physiology, vol. 41, no. 10, pp. 843-849, 1995.

[52] B. S. Lanne, P. Ivarsson, P. Johnsson, G. Bergström, and A. B. Wassgren, "Biosynthesis of 2-methyl-3-buten-2-ol, a pheromone component of Ips typographus (Coleoptera: Scolytidae)," Insect Biochemistry, vol. 19, no. 2, pp. 163-167, 1989.

[53] P. Ivarsson, F. Schlyter, and G. Birgersson, "Demonstration of de novo pheromone biosynthesis in Ips duplicatus (Coleoptera: Scolytidae): inhibition of ipsdienol and E-myrcenol production by compactin," Insect Biochemistry and Molecular Biology, vol. 23, no. 6, pp. 655-662, 1993. 
[54] S. J. Seybold, D. R. Quilici, J. A. Tillman, D. Vanderwel, D. L. Wood, and G. J. Blomquist, "De novo biosynthesis of the aggregation pheromone components ipsenol and ipsdienol by the pine bark beetles Ips paraconfusus lanier and Ips pini (Say) (Coleoptera: Scolytidae)," Proceedings of the National Academy of Sciences of the United States of America, vol. 92, no. 18, pp. 8393-8397, 1995.

[55] C. Tittiger, G. J. Blomquist, P. Ivarsson, C. E. Borgeson, and S. J. Seybold, "Juvenile hormone regulation of HMG-R gene expression in the bark beetle Ips paraconfusus (Coleoptera: Scolytidae): implications for male aggregation pheromone biosynthesis," Cellular and Molecular Life Sciences, vol. 55, no. 1, pp. 121-127, 1999.

[56] G. M. Hall, C. Tittiger, G. L. Andrews et al., "Midgut tissue of male pine engraver, Ips pini, synthesizes monoterpenoid pheromone component ipsdienol de novo," Naturwissenschaften, vol. 89, no. 2, pp. 79-83, 2002.

[57] J. B. Nardi, A. G. Young, E. Ujhelyi, C. Tittiger, M. J. Lehane, and G. J. Blomquist, "Specialization of midgut cells for synthesis of male isoprenoid pheromone components in two scolytid beetles, Dendroctonus jeffreyi and Ips pini," Tissue and Cell, vol. 34, no. 4, pp. 221-231, 2002.

[58] P. Sandstrom, W. H. Welch, G. J. Blomquist, and C. Tittiger, "Functional expression of a bark beetle cytochrome P450 that hydroxylates myrcene to ipsdienol," Insect Biochemistry and Molecular Biology, vol. 36, no. 11, pp. 835-845, 2006.

[59] P. Sandstrom, M. D. Ginzel, J. C. Bearfield, W. H. Welch, G. J. Blomquist, and C. Tittiger, "Myrcene hydroxylases do not determine enantiomeric composition of pheromonal ipsdienol in Ips spp.," Journal of Chemical Ecology, vol. 34, no. 12, pp. 1584-1592, 2008.

[60] F. J. Ayala, "Molecular clock mirages," BioEssays, vol. 21, no. 1, pp. 71-75, 1999.

[61] A. I. Cognato, S. J. Seybold, D. L. Wood, and S. A. Teale, "A cladistic analysis of pheromone evolution in Ips bark beetles (Coleoptera: Scolytidae)," Evolution, vol. 51, no. 1, pp. 313 318, 1997. 

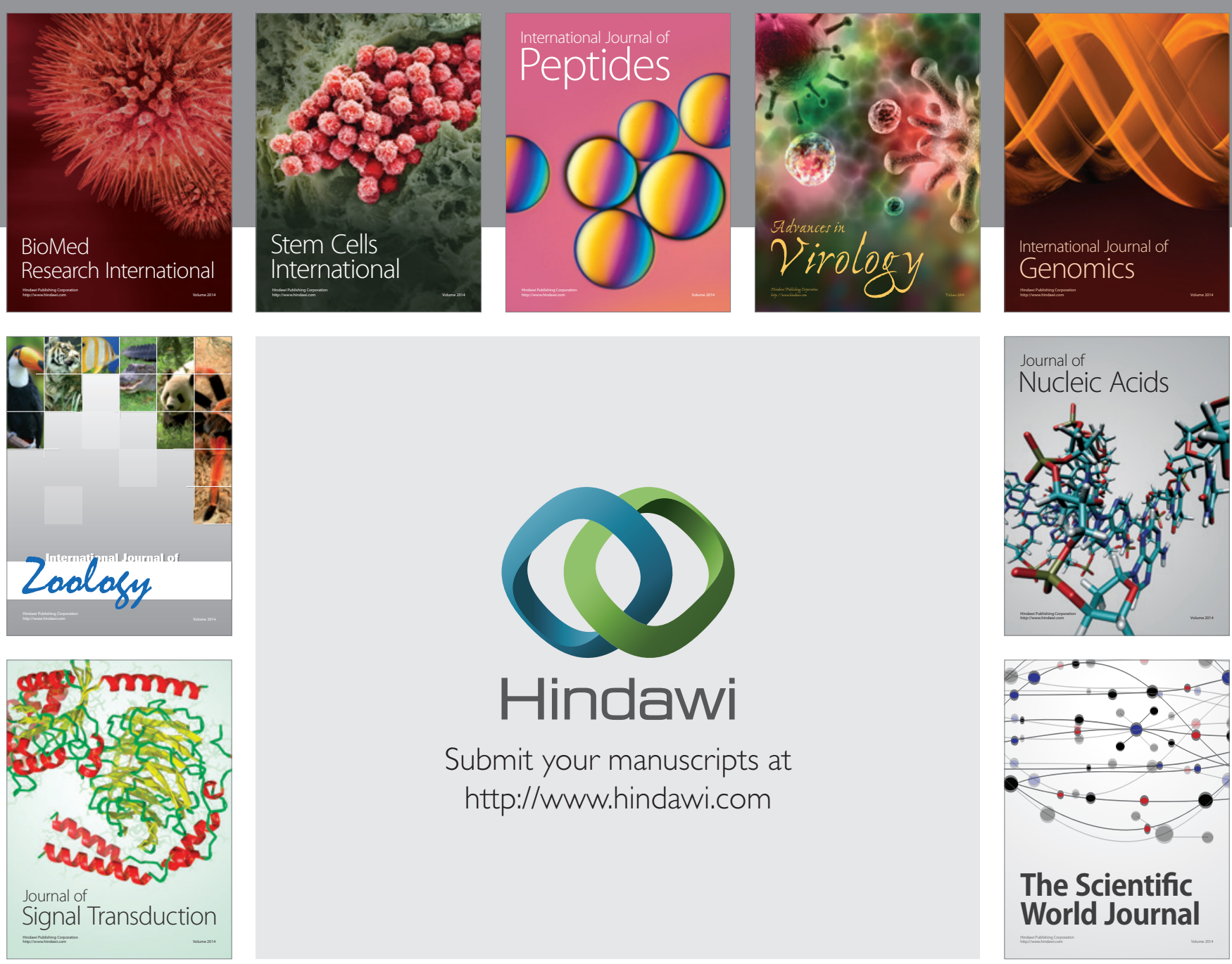

Submit your manuscripts at

http://www.hindawi.com
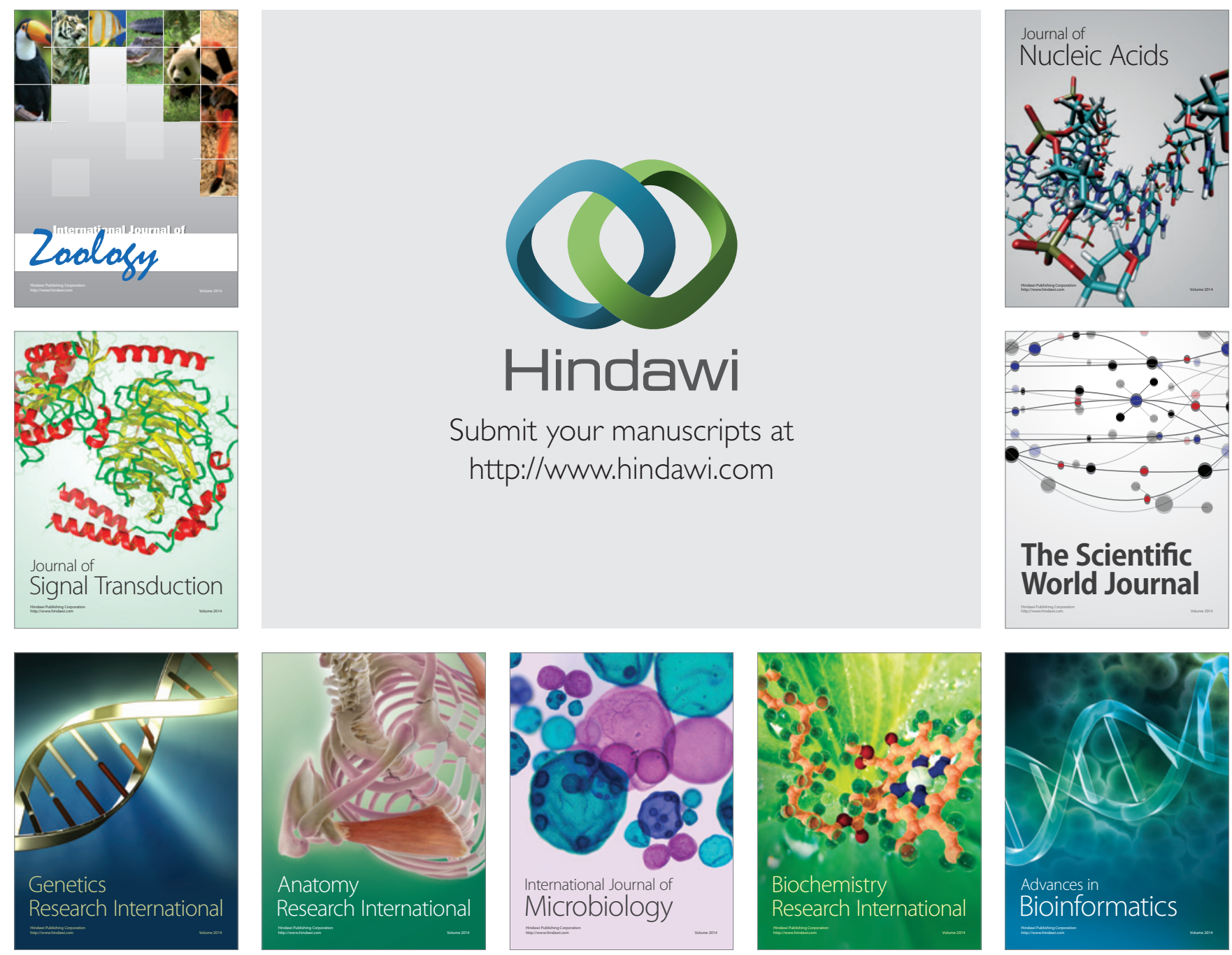

The Scientific World Journal
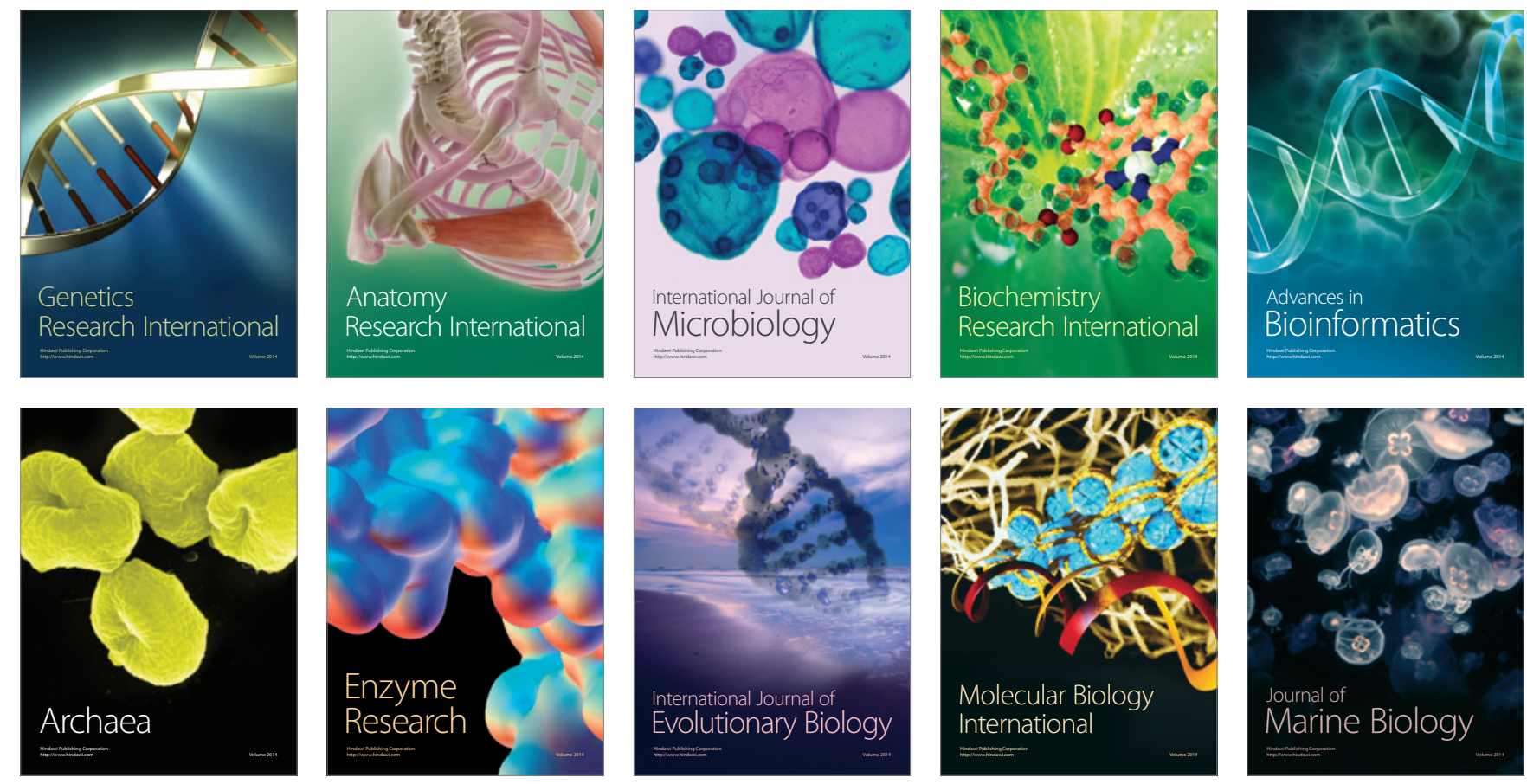